Ethiopian Journal of Environmental Studies \& Management 9(3): 267 - 277, 2016.

ISSN:1998-0507

doi: http://dx.doi.org/10.4314/ejesm.v9i3.2

Submitted: September 15, 2015

Accepted: April 19, 2016

\title{
ANALYSIS OF ADHERENCE TO APPLICATION RATE AND PERCEPTION OF PESTICIDES USE ON ENVIRONMENT AMONG COCOA FARMERS IN NIGERIA
}

\author{
*OWOMBO, P.T., ${ }^{1}$ IDUMAH, F.0. ${ }^{1}$ ONUNKUN, $0 .^{2}$ AND ADESINA, C.A. ${ }^{3}$ \\ ${ }^{1}$ Moist Forest Research Station, Forestry Research Institute of Nigeria, Benin City, Nigeria \\ ${ }^{2}$ Department of Agricultural Science, Adeyemi College of Education, Ondo, Nigeria \\ ${ }^{3}$ Department of Agricultural Economics and Extension, Bowen University, Iwo, Nigeria
}

\begin{abstract}
In developing countries, pesticides application is characterised by gross misuse among farmers which have threatened the environment. The study was therefore conducted to investigate adherence to pesticides application rate and perception of use on the environment among cocoa farmers in Nigeria. A multi-stage sampling procedure was employed to select 480 respondents for the study. Data collected were analysed with the aid of descriptive statistics and probit model. Analysis revealed that majority of the respondents (68\%) did not adhere to pesticides application rate as contained in the pesticides label. Farmers' adherence to pesticides application rate was positive and significantly influenced by level of education of household head and access to radio. Majority of the respondents perceived that the use of pesticides has negative impact on the environment. The farmers therefore need education for the rightful application of pesticides according to the recommended rate.
\end{abstract}

Key Words: Adherence, Pesticides, Application, Perception, Environment, Cocoa farmers

\section{Introduction}

Cocoa is a major export crop in Nigeria. Nigeria was at a time recorded a production level of 800,000 tonnes annually, making her the second largest producer in the world. Nigeria is today the $4^{\text {th }}$ largest producer in the world after Cote d'Ivoire, Indonesia and Ghana, with a production level of 400,000 tonnes per annum (FAO, 2011). The major production (about $70 \%$ ) in the country takes place in the South-Western part of the country. The worrisome decline in the output level of cocoa in Nigeria has been traced to several factors among which are pests and diseases (Tijani, 2005), land degradation and variation in the climates (Owombo et al., 2014). Conventionally, farmers have employed pesticides for the control of pests and diseases for the purposes of maximum yield and continuous flow of income (Tijani et al., 2008). According to Shama et al. (2012), pesticides application is characterised by gross misuse as most farmers either do not know or follow the recommended application rate due to low literacy level, lack of information or a combination of both. Pesticides misuse is becoming a serious concern mainly in the commercial areas of agricultural production, where farmers are suffering from environmental

*Corresponding Author: Owombo, P.T.

Email: owombopaul@gmail.com 
pollution and health hazards (Adeola, 2012; Sharma et al. (2012).

Pesticides misuse is due mainly to non-adherence to application rate and safety precautions, deficit of information on first aid, lack of understanding of the antidotes written on the label, use of faulty or leaking spraying equipment, lack of the use of protective gear as well as non-use of protective clothing during handling (Damalas et al., 2006; Ajayi and Akinnifesi, 2008; Sosan and Akingbohungbe, 2009; Adeola, 2012; Owombo et al., 2014).

None adherence to application as contained in the antidotes given by label constitutes a major problem among the farmers and makes exposure severe. The incidence of poisoning is on the increase because of the exposure of the farmers to highly toxic substances contained in the pesticides (Naidoo et al., 2010). Some past studies such as Sosan and Akingbohungbe (2009), Tijani (2006) and Owombo et al. (2014) for example have investigated occupational insecticide exposure, perception and adherence to safety measures among cacao farmers in southwestern Nigeria. However, no known studies have been conducted to investigate determinants of pesticides application rate and perception of use on environment among cocoa farmers in Nigeria. The study will thus provide answers to the following questions: what are socio-economic characteristics of the respondents? How do the farmers perceive the effects of pesticides use on the environment? What are the determinants of application rate among the farmers?

\section{Objectives of the Study}

The broad objective of the study is to investigate farmers' adherence to pesticides application rate and perception of use on environment among cocoa farmers in Nigeria.

The specific objectives of the study are to;

(a) examine the socio-economic characteristics of the respondents;

(b) investigate farmers' adherence to pesticides application rate and determinants of adherence to application rate among the respondents.

(c) assess farmers' perception of pesticides use on the environment

\section{Methodology \\ Area of study}

The study was conducted in the Southwestern, Nigeria, which is the major cocoa production belt of the country. The zone is made up of Six States-Ekiti, Ogun, Lagos, Ondo, Osun and Oyo States. The zone is purposively selected for the study based on the predominance of cocoa production in the area. The zone lies between Longitude $4^{\circ} 30^{\prime}$ and $6^{\circ} 0^{\prime}$ east of the Greenwich Meridian and Latitude $4^{\circ} 45^{\prime}$ and $8^{\circ} 15^{\prime}$ north of Equator. The zone is a tropical coastal wetland with mean annual rainfall of about $2800 \mathrm{~mm}$, mean number of rainy days of between 160 and 180. Mean relative humidity is between $70-80 \%$, mean annual temperature is about $28^{\circ} \mathrm{C}$, mean daily temperature is $26^{\circ} \mathrm{C}$, mean daily minimum temperature is $22^{\circ} \mathrm{C}$, and mean daily maximum temperature is $26.7^{\circ} \mathrm{C}$ (ref.). The land in the area is characterized by various physical features like hills, lowland, rivers, creeks and lagoons. The people are predominantly smallholder farmers cultivating both permanent plantation crops like cocoa, cola, oil palm, etc. for cash and arable crops like yam, cassava, maize and cocoyam, etc. for the dual purposes of 
family consumption and cash. Farming activities are usually carried out using simple farm tools with limited application of modern implements.

\section{Sampling Techniques and Data Collection}

Multistage sampling technique was employed to select respondents for the study. The first stage involved purposive selection of Ekiti, Ondo and Osun States, Southwestern, Nigeria, based on the predominance of the enterprise. In the second stage, 4 Local Government Areas (LGAs) were purposively selected in each of the states based on the predominance of cocoa production in those LGAs making 12 LGAs. In the third stage, two villages per LGA were randomly selected making a total of 24 villages in all. In the final stage, 20 cocoa farmers from each of the villages were randomly selected for interview. A total of 480 respondents were selected in all. Data were collected on the socioeconomic and institutional characteristics of the respondents such sex, age, credit access, level of education, information sources, off-farm income, farming experience; farm factors such as farm size, pesticides used as well as adherence to pesticides application rate were also collected. Data collected were analyzed using SPSS version 16.0 and STATA 12.0.

\section{Analytical Technique}

Descriptive statistics and probit regression model were used for the analysis. The descriptive statistics was employed to describe the pesticides (insecticides and fungicides) commonly used by the respondents, farmers perceived effects on the environment and socio-economic characteristics of the respondents.

\section{The Probit Regression Model}

The probit regression model uses the cumulative distribution function (CDF) to explain the behaviour of a dichotomous dependent variable. Given the assumption of normality, the probability that $I^{*}{ }_{i}$ is less than or equal to $I_{i}$ can be computed from the normal CDF as

$$
\begin{aligned}
& \mathrm{P}_{\mathrm{i}}=\mathrm{P}(\mathrm{Y}=1 / \mathrm{X}) \\
& =\mathrm{P}\left(\mathrm{I}_{\mathrm{i}} *<\mathrm{I}_{\mathrm{i}}\right) \\
& =\mathrm{P}\left(\mathrm{Z}_{\mathrm{i}}<\mathrm{B}_{1}+\mathrm{B}_{2} \mathrm{X}_{\mathrm{i}}\right) \\
& =\mathrm{F}\left(\mathrm{B}_{1}+\mathrm{B}_{2} \mathrm{Xi}\right)
\end{aligned}
$$

where $I^{*}=$ critical or threshold level of the index, such that if $I_{i}$ exceeds $I^{*}$, the family will adopt, otherwise it will not. $\mathrm{P}$ $(\mathrm{Y}=1 / \mathrm{X})$ is the probability that an event occurs given the values of $\mathrm{X}$, or explanatory variable(s) and where $Z_{\mathrm{i}}$ is the normal variable i.e $\mathrm{Z} \sim \mathrm{N}(0, \mathrm{Q} 2)$.

The probit model employs probability in its analysis. As said previously, probit uses the cumulative normal distribution. The probit model is defined as;

$\operatorname{Pr}(\mathrm{y}=1 / \mathrm{X})=\Phi(\mathrm{xb})$

where $\Phi$ is the standard cumulative normal probability distribution and $\mathrm{xb}$ is called the probit score or index.

Since $\mathrm{xb}$ has a normal distribution. The interpretation of a probit coefficient is that one-unit increase in the predictor leads to increasing the probit score by $b$ standard deviations.

The log- likelihood function for probit model is;

In $\mathrm{L}=\sum_{w_{j}} \operatorname{In} \theta\left(\mathrm{x}_{\mathrm{j}} \mathrm{b}\right)+\sum_{\mathrm{wj}} \operatorname{In}\left(1-\theta\left(\mathrm{x}_{\mathrm{j}} \mathrm{b}\right)\right.$ where $\mathrm{w}_{\mathrm{j}}$ denotes optional weights. The model relating to adherence to application rate is specified as follows; 
$P_{i}=f\left(\beta_{0}+\beta_{1}\right.$ AGEHH $+\beta_{2}$ EDULHH $+\beta_{3}$ EDULSP $+\beta_{4}$ FARMEXP $+\beta_{5}$ EXTCON + $\left.\beta_{6} A S S M E M+\beta_{7} A C C R A D+\beta_{8} A C C T V+\varepsilon_{i}\right)$

where,

$\mathrm{P}_{\mathrm{i}}=$ adherence status measured as dummy ( $1=$ adherence, $0=$ non- adherence $)$

$A G E H H=$ Age of household head

$E D U L H H=$ Level of educational of household head

$E D U L S P=$ Level of education of spouse

FARMEXP $=$ Farming experience

EXTCON= Extension contact

ASSMEM = Association membership

$A C C R A D=$ Access to radio

$A C C T V=$ Access to television

Table1: Expected signs of independent variables

\begin{tabular}{ll}
\hline Variable & Expected signs \\
\hline Age of household head & $+/-$ \\
Level of education & + \\
Level of education level of spouse & + \\
Farming experience & $+/-$ \\
Extension contact & + \\
Membership of association & + \\
Access to radio & + \\
Access to television & + \\
\hline
\end{tabular}

Results and Discussion

Socioeconomic Characteristics of the Respondents

Table 2 reveals the socio-economic and institutional characteristics of the respondents. The results in the table reveal that the means of age, level of education of household head and household size were $49.3 \pm 11.9,9 \pm 4.6$ and $8 \pm 4.1$, respectively. This implies that farmers in the area were still in their active ages. The mean level of education of the spouses of the respondents in years was $5.1 \pm 2.3$ years. This implies that the level of education of their spouses were low in the study area. Also, the means of farming experience, farm size, cocoa income and off-farm income were $21 \pm 9.3, \quad 1.9 \pm 1.1, \quad 1619.8 \pm 876.2$ and $155.8 \pm 87.2$, respectively. The mean farming experience shows that the farmers were experienced. The mean farm size showed that the farmers are small holder farmers. The off-farm income recorded by the farmers in the area revealed that the farmers engaged in activities other than cocoa farming. The cocoa enterprise is dominated by male farmers as 67 percent of the respondents were male while just 33 percent of them were female. Majority of the farmers $(89 \%)$ do not have access to credit while just 19 percent of the respondents had access to credit. This implies that farmers in the area have low access to credit. This is in agreement with studies (Owombo et al., 2014; Akinola et al, 2007) that majority of farmers in Nigeria do not have access to credit. Similarly, majority of the respondents (82\%) do not 
have access to extension services while just 18 percent of them had access to credit. The low access of respondents to extension services may be due to poor funding of extension education in Nigeria and it is in agreement with previous studies as (Akinola et al., 2007; Owombo et al., 2014). On membership of association, 53 percent of the respondents belong to one or two village associations while 47 percent of them do not belong to any village associations in the area. The high proportion of village association membership may be traceable to the probable benefits accruable to the members. The major source of information on pesticides use is friends as 58 percent of the cocoa farmers indicated that they source information from friends. However, 3 percent, 4 percent and 29 percent indicated radio, extension agents and others as major information sources, respectively. Other sources of information indicated by the respondents were pesticides merchants, NGOs and cocoa traders. Majority of the respondents $(61 \%)$ owned the cocoa plots on which they operate while 22 percent of them operate on rented plots. However, 17 percent of the respondents operate on both owned and rented plots. The people who own as well as operate on rented plot may be due to the uneconomic size of plot owned (Fraser, 2002)

Table 2: Socio-economic and institutional characteristics of respondents

\begin{tabular}{ll}
\hline Variable & Mean \pm SD \\
\hline Age (years) & $49.3 \pm 11.9$ \\
Level of education of household head (years) & $9 \pm 4.6$ \\
Level of education of spouse (years) & $5.1 \pm 2.3$ \\
Household size & $8 \pm 4.1$ \\
Farming experience (years) & $21 \pm 9.3$ \\
Farm size (hectare) & $1.9 \pm 1.1$ \\
Cocoa income (\$) & $1619.8 \pm 876.2$ \\
Off-farm income $(\$)$ & $155.8 \pm 87.2$ \\
& $\%$ \\
Sex & \\
Male & 67 \\
Female & 33 \\
Total & 100 \\
& \\
Credit access & \\
Yes & 19 \\
No & 81 \\
Total & 100 \\
Extension visits & \\
Yes & \\
No & 18 \\
Total & 82 \\
Membership of association & 100 \\
Yes & \\
No & \\
\hline & 53 \\
\hline
\end{tabular}




\begin{tabular}{ll}
\hline Total & 100 \\
Major information source on pesticides use & \\
Friends & 64 \\
Radio & 3 \\
Newspaper & 0 \\
Extension agents & 4 \\
Others & 29 \\
Total & 100 \\
Ownership of cocoa plot & \\
Owned & 61 \\
Rented & 22 \\
Both & 17 \\
Total & 100 \\
\hline
\end{tabular}

\section{Adherence Typology and Reasons for} Non-adherence

Figures 1 and 2 reveal the adherence typology of the respondents and the reasons for non-adherences, respectively. The results in figure 1 reveal that while 63 percent of the respondents indicated non-adherence to pesticides application rate, 37 percent of them indicated adherence to the application rate of pesticides as contained on the pesticides' label. This implies that majority of the respondents do not comply with the pesticides application rate. It can be inferred from the above that most farmers misuse or make an abuse use of pesticides on plots. The misuse as well as the abuse use may be the major reasons the impact of pesticides is severe on both human health and the environment (Adeola, 2012).

However, several reasons were given by the respondents for their nonadherence to pesticides application rate in the study area. Majority of the respondents $(43 \%)$ indicated inability to read the instruction on the pesticides label as the major reasons for nonadherence to application rate. However, 36 percent and 21 percent indicated fear of effectivity and following instruction from friends respectively, as the responsible factors for non-adherence to application rate. Studies (Ejembi et al., 2006) have shown that the literacy level of farmers in Nigeria is low. Also, farmers have confidence in what their colleagues do or practice. 


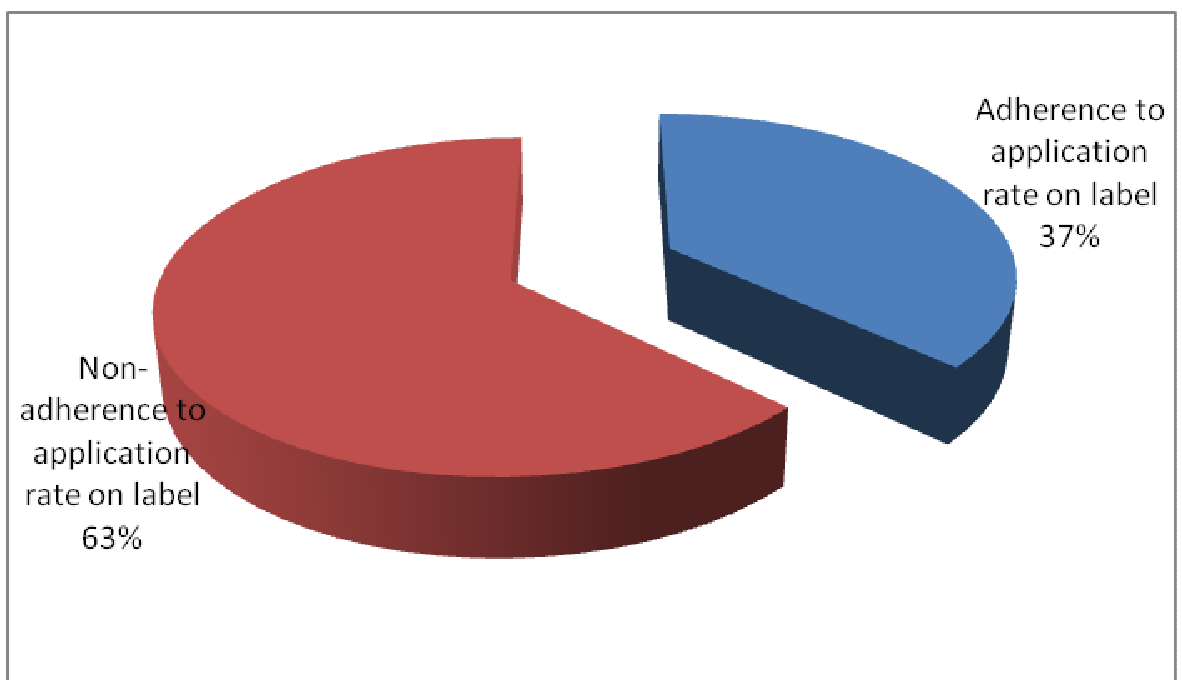

Figure 1: Adherence typology

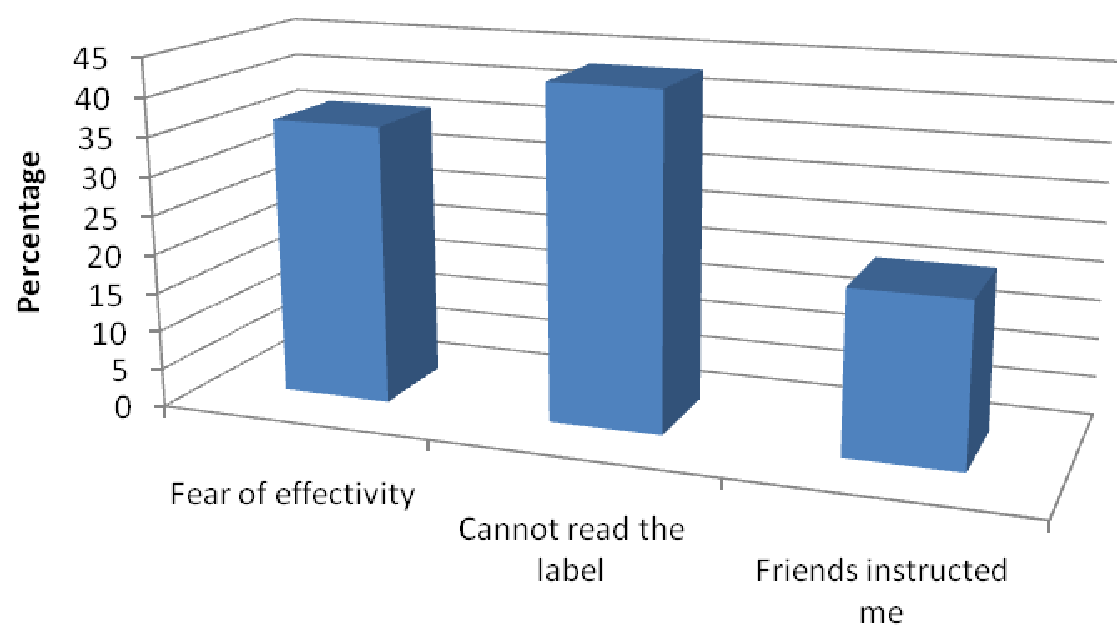

Reasons for non-adherence to label on pesticides

Figure 2: Reasons for non-adherence

\section{Results of Probit Model}

Table 3 shows the results of the probit regression model. The results in the table showed that the diagnostic parameters; Log-Likelihood function and the Restricted Log-Likelihood function values were -6.8 and -34.6 , respectively. These diagnostic parameters measure the fitness of the entire model which is significant at 1 percent level of probability. The results in the table further revealed that while level of education of the household head and access to radio were positive and significantly influenced farmers' adherence to recommended application rate, farming experience was negative and significantly influenced adherence to application rate. Level of education of the household head, farming experience and access to radio were significant at 5 percent, 1 percent and 1 percent alpha levels of probability, respectively. The results of the marginal effects revealed 
that an increase in the level of education of the household head by 1 year and access to radio by a unit will increase probability of adherence to application rate by 7.61 percent and 15.06 percent, respectively. The results are in agreement with the expectation of the study that level of education of household head and access to radio are expected to positively correlate with the farmers' adherence to application rate in the area. However, an increase in the farmers' farming experience by 1 year will decrease the probability of adherence by 1.79 percent. This is in agreement with the expectation of the study that farming experience could have positive or negative effects on farmers' adherence to application rate. Age, though not significant, but had inverse relationship with farmers' adherence to application rate. This is in agreement with the expectation of the study that the age of the farmers is expected to be negatively related to the farmers' adherence to application rate because the older a farmer is the less the likelihood that he will practice precision agriculture (Akinola et al., 2007). The level of education of the spouse of the respondents though was not significant but had positive relationship with the adherence to application rate. The membership of association also has positive relationship with farmers' adherence to application rate. This is also in agreement with the expectation of the study.

Table 3: Results of probit model

\begin{tabular}{lll}
\hline Variable & Marginal effect & P-value \\
\hline Age & $-0.0187(0.0228)$ & 0.4129 \\
Level of education of household head & $0.0761^{* *}(0.0348)$ & 0.0287 \\
Level of education of spouse & $0.0272(0.0321)$ & 0.3316 \\
Farming experience & $-0.0179^{* * *}(0.0056)$ & 0.0013 \\
Extension contact & $0.0321(0.0390)$ & 0.4110 \\
Membership of association & $0.1416(0.08719)$ & 0.1043 \\
Access to radio & $0.1506^{* * *}(0.5800)$ & 0.0094 \\
Access to television & $0.034(0.0430)$ & 0.2311 \\
\hline
\end{tabular}

Figures in parenthesis are standard errors

$* * *$ significant at alpha level of $1 \%$

**significant at alpha level of 5\%

The values in parenthesis are standard errors

\section{Pesticides Used by the Respondents According to Trade Name}

The results of the multiple responses in Table 4 reveal the pesticides used by the respondents according to trade name. The cocoa farmers in the area use a broad range of pesticides (insecticides and fungicides) with different trade names.
The insecticides used by the farmers were Dursban48EC (67\%), Actara25WG (73\%) and Proteus 170O-TEQ (56\%), respectively while the various fungicides use according to trade name were Funguran- ${ }^{\mathrm{OH}}$ (82\%), Champ DP (45\%), Ridomil gold 66WP (85\%) and Nordox 75WP (73\%0, respectively. 
Analysis of Adherence to Application Rate and Perception................0WOMBO et al.

Table 4: Pesticides used by the respondents according to trade name

\begin{tabular}{|c|c|c|c|c|c|}
\hline Trade Name & Type & $\begin{array}{l}\text { Toxicity } \\
\text { code }\end{array}$ & $\begin{array}{l}\text { Active } \\
\text { ingredient }\end{array}$ & $\begin{array}{l}\text { \% composition } \\
\text { of active } \\
\text { ingredient }\end{array}$ & $\begin{array}{l}\% \\
\text { of } \\
\text { farmers }\end{array}$ \\
\hline \multicolumn{6}{|l|}{ Insecticides } \\
\hline Dursban48EC & Organophosphate & 3 & Chorpyrifos & 75 & 67 \\
\hline Actara25WG & Organophosphate & 3 & Thiamethoxam & 25 & 73 \\
\hline $\begin{array}{l}\text { Proteus } 170 \text { O- } \\
\text { TEQ }\end{array}$ & Pyrethroids & 3 & Deltametrin & 11.75 & 56 \\
\hline \multicolumn{6}{|l|}{ Fungicides } \\
\hline Funguran- ${ }^{\mathrm{OH}}$ & Copper & 1 & Copper hydroxide & 77 & 82 \\
\hline Champ DP & Dithiocarbamate & 1 & Copper hydroxide & 57 & 45 \\
\hline $\begin{array}{l}\text { Ridomil Gold } \\
66 \mathrm{WP}\end{array}$ & Copper & 1 & Metalaxyl-M & 45.3 & 55 \\
\hline Nordox 75WP & Copper & 3 & Cuprous oxide & 75 & 61 \\
\hline Kocide & Copper & 3 & Cuprous oxide & 40 & 66 \\
\hline
\end{tabular}

Multiple responses

Toxicity code: $1=$ very toxic; $2=$ toxic; $3=$ harmful

Farmers' Perceived Effects of Pesticides Use on the Environment

Table 5 reveals the farmers' perceived negative effects of pesticides use on the environment. The farmers' perceived negative effects on the environment include soil contamination $(63.8 \%)$, pollution of streams and rivers (71.7\%); contribution to air pollution $(55.3 \%)$; endangering biodiversity (57.2\%); harmful to beneficial organisms
(49.7\%) and harmful to non-target organisms. This implies that the cocoa farmers in the area perceived pesticides use as being harmful to both the biotic and abiotic environment. This is in agreement with Sosan and Akingbohungbe (2009) and Adeola (2012) that pesticides use is perceived harmful to the environment by cocoa farmers in Nigeria.

Table 5: Farmers' perceived effects of pesticides use on the environment

\begin{tabular}{ll}
\hline Perception & Percentage \\
\hline Soil contamination & 63.8 \\
Pollution of streams and rivers & 71.7 \\
Contribution to air pollution & 55.3 \\
Endanger biodiversity & 57.2 \\
Harmful to beneficial organisms & 49.7 \\
Harmful to non-target organisms & 68.9 \\
\hline
\end{tabular}

Multiple responses

\section{Conclusion}

Pesticides use in developing countries, Nigeria inclusive is characterised by gross misuse and abuse use. These are traceable either to non- adherence to application rate, safety precautions or pesticides exposure. The study was thus conducted to investigate farmers' adherence to pesticides application rate as contained on the 
pesticides label as well as their perception of pesticides on the environment. The study concluded that farmers in the area were in their active ages with low level of education. They engage in activities other that farming. Majority of the farmers (63\%) do not adhere to pesticides application rate as contained on the pesticides label. Farmers' adherence to the application rate was positive and significantly influenced by level of education of household head, extension contact and access to radio. Majority of the respondents; 63.8 percent, 71.7 percent, 55.3 percent, 57.2 percent and 68.9 percent perceived that pesticides contaminate the soil, pollute streams and rivers, contribute to air pollution, endanger biodiversity as well as harmful to non-target organisms. Policy framework that would create opportunity for farmers to be informally educated as well as have access to extension services on pesticides application rate in order to reduce pesticides exposure and impact on the environment should be put in place.

\section{References}

Adeola, R.G. (2012). Perceptions of Environmental Effects of Pesticides Use in Vegetable Production by Farmers in Ogbomoso, Nigeria. Agriculture \& Biology, 12(4):72-78.

Akinola, A.A., Arega, D.A., Adeyemo, R., Sanogo D., Olanrewaju, A.S., Nwoke, C., Nziguheba, G. and Diels, J. (2007). Determinants of adoption and intensity of use of balanced nutrient management systems technologies in the northern guinea savanna of Nigeria. African Association Agricultural Economics Conference Proceedings, 111-118.
Ejembi, S.A., Ejembi, E.P. and Okwoche, V.A. (2006). Problems of Effective Adoption Decision among Farmers in Makurdi, Benue State: The Relevance of Choice of Communication Methods" Proceeding of 11th Annual Conference of Agricultural Extension Society of Nigeria, Held between 3rd and 6th April, 2006. pp 235-241.

Fraser, E D.G. (2002). Land tenure and agricultural management: Soil conservation on rented and owned fields in southwest British Columbia. Agriculture and Human Values, 21:73-79.

Naidoo, S., London, L. and Rother, H.A. (2010). Pesticide safety training and practices in women working in small-scale agriculture in South Africa. Journal of Occupational Environment Medicine, 67(12):823828.

Owombo, P.T., Idumah, F.O and Afolayan, A.F. (2014). Assessing Factors Affecting Adherence to Safety Precautions in Pesticides Use among Cocoa Farmers in Nigeria. Ethiopian Journal of Environmental Studies and Management, 7:810-820.

Sharma, D. R., Thapa, R. B., Manandhar, H. K., Shrestha, S. M. and Pradhan, S. B. (2012). Use of Pesticides in Nepal and Impacts an Human Health and Environment. The Journal of Agriculture and Environment, Vol. 13, 67-74.

Sosan, M.B. and Akingbohungbe, A.E. (2009). Occupational insecticide exposure and perception of safety measures among cacao farmers in southwestern Nigeria. Arch. 
Analysis of Adherence to Application Rate and Perception.................0WOMBO et al.

Environ. Occup. Health, 64:185193.

Tijani, A.A. (2005). Profitability of Fungicide Use Decisions Among Cocoa Farmers in Southwestern Nigeria. J. Soc. Sci., 11(2):165-171.

Tijani, A.A. (2006). Pesticide Use Practices and Safety Issues: The Case of Cocoa Farmers in Ondo
State, Nigeria. Journal of Human Ecology, 19(3):183-190.

Tijani, A.A., Agboola, A.F. and Adejobi, A.O. (2008). Factors Influencing the adoption of Indigenous Pest Control Methods Among Rural Development Programme RuDeP Cocoa Farmers in Osun State, Nigeria. Journal of Agriculture and Rural Development, 2:108-123. 